\title{
Analisis Yuridis Atas Tenaga Keperawatan Yang Melakukan Pelecehan Seksual Kepada Pasien
}

\author{
Dhian Yuli Prasetyo \\ Fakultas Hukum Universitas Islam Indonesia Yogyakarta Indonesia \\ Jln. Cik Di Tiro No. 1, Yogyakarta, Indonesia 55223 \\ prasetyodhian@gmail.com
}

\begin{abstract}
This study discusses two problems: First, what is the basis for the policy of sexual harassment by nursing staff against patients in statutory regulations; and second, what is the urgency of lex specialis in criminal governance for nursing staff who sexually abuse patients. This study uses a normative juridical method with a statutory approach. Data collection was carried out by literature study with qualitative analysis. The results of the study concluded that: First, the policy on the criminal act of sexual harassment by nursing staff against patients still applies the general legal rules to decide on perpetrators who have the nursing profession, namely based on Article 290 paragraph (1) of the Criminal Code; and Second, the urgency of the lex specialis in regulating criminal acts of sexual harassment by nursing personnel against patients is because the existing regulations have not been able to fully address the problem of sexual harassment, especially in the protection of victims.
\end{abstract}

Key Words: Nursing staff; patients; sexual harassment

\begin{abstract}
Abstrak
Penelitian ini membahas dua permasalahan yakni: Pertama,bagaimana dasar kebijakan tindak pidana pelecehan seksual oleh tenaga keperawatan terhadap pasien dalam peraturan perundang-undangan; dan kedua, apa sajakah urgensi lex spesialis dalam pengaturan pidana bagi tenaga keperawatan yang melakukan pelecehan seksual terhadap pasien. Penelitian ini menggunakan metode yuridis normatif dengan pendekatan undang-undang. Pengumpulan data dilakukan dengan studi kepustakaan dengan analisis kualitatif. Hasil penelitian menyimpulkan bahwa: Pertama, Kebijakan atas tindak pidana pelecehan seksual oleh tenaga keperawatan terhadap pasien masih menggunakan aturan hukum yang bersifat umum untuk memutus pelaku yang memiliki profesi perawat yaitu berdasar pada Pasal 290 ayat (1) KUHP; dan Kedua, urgensi lex spesialis pengaturan tindak pidana pelecehan seksual oleh tenaga keperawatan terhadap pasien adalah karena peraturan yang ada belum mampu mengatasi secara maksimal masalah pelecehan seksual terutama dalam perlindungan terhadap korban.
\end{abstract}

Kata-kata Kunci: Pasien; pelecehan seksual; tenaga keperawatan 


\section{Pendahuluan}

Perlindungan hukum merupakan instrumen utama dalam berdirinya suatu negara hukum. Perlindungan hukum merupakan perwujudan kewajiban negara terhadap perlindungan hak warga negara. Indonesia wajib melindungi warga negaranya sebagai negara hukum.

Negara hukum Indonesia dibentuk berdasarkan pembukaan UndangUndang Dasar 1945, alinea kedua yang menyatakan bahwa Indonesia yang merdeka, bersatu, berdaulat, adil dan makmur. Azhari menyatakan bahwa apabila kalimat pada alinea kedua dihubungkan dengan alinea keempat yang memuat tujuan negara yang berbunyi sebagai berikut:

Melindungi segenap bangsa Indonesia dan seluruh tumpah darah Indonesia dan untuk mewujudkan kesejahteraan umum, mencerdaskan kehidupan bangsa dan ikut melaksanakan ketertiban dunia yang berdasarkan kemerdekaan, perdamaian abadi dan keadilan sosial. ${ }^{1}$

Indonesia mengatur perlindungan hukum dalam suatu peraturan hak asasi manusia dalam Undang-Undang Negara Republik Indonesia Tahun 1945 Pasal 28. Perlindungan hukum salah satunya mengenai hak perempuan dan anak-anak sebagaimana disebutkan dalam Undang-Undang Negara Republik Indonesia Tahun 1945.

Pemerintah harus dapat memberikan perlindungan dan kepastian hukum. Guna mewujudkan tujuan perlindungan hukum, maka pemerintah mengesahkan Undang-Undang Hak Asasi Manusia. Namun dalam perkembangannya, UndangUndang tersebut belum dapat menjangkau jenis-jenis kejahatan yang baru dan belum memberikan efek jera kepada pelaku.

Berdasarkan lingkungan terjadinya tindak pelecehan seksual, penulis memperoleh data awal sebanyak empat lokasi sebagai berikut:

Pertama, pelecehan seksual di industri perfilman. Dilatarbelakangi industri film yang terdesentralisasi di Jakarta, Bandung dan Yogyakarta sehingga membuat korban yang juga pendatang baru merasa tidak berdaya ketika dilecehkan oleh seniornya. Istilah lain, penyebab utamanya ialah adanya relasi kuasa. ${ }^{2}$ Pelecehan seksual di industri film belum ada yang pernah disidangkan di Indonesia karena merupakan hal yang baru. Namun sudah ada bantuan administratif melalui formulir yang disediakan Yayasan Bersama Project dan

1 Azhari, Negara Hukum, UI Press, Jakarta, 1955, hlm. 116.

2 Aulia Adam, "Pelecehan Seksual di Industri Film dan Suara Nyalang Mian Tiara", https://tirto.id/pelecehanseksual-di-industri-film-dan-suara-nyalang-mian-tiara-ey1Q, diakses tanggal 17 Februari 2020. 
dukungan moral melalui komentar terhadap utas (thread) yang dibagikan di sosial media twitter.

Kedua, pelecehan seksual di institusi pendidikan. Pelecehan di Institusi Pendidikan dapat terjadi pada jenjang formal maupun non formal. Pada jenjang formal, pelecehan seksual banyak terjadi di Kampus. Contohnya pelaku pelecehan disalah satu Universitas Islam di Bandar Lampung ialah seorang dosen senior. Dosen tersebut divonis bersalah dan dihukum satu tahun penjara pada 17 September 2019. Vonis tersebut lebih ringan daripada tuntuan Jaksa yakni dua tahun enam bulan penjara. Pelaku yang sudah berstatus terdakwa terbukti melakukan kejahatan berdasar KUHP Pasal 290 ayat (1). ${ }^{3}$

Selain kampus, penulis juga menemukan pelecehan seksual di tingkat sekolah dasar. Seorang guru honorer di salah satu sekolah dasar negeri di Kabupaten Limapuluh Kota, Payakumbuh, Provinsi Sumatera Barat terbukti bersalah menyodomi duabelas muridnya disertai ancaman sejak 2017. Guru tersebut akhirnya divonis hukuman 20 tahun penjara pada 2 Oktober 2019.

Pada jenjang non-formal penulis menemukan dua berita kasus pelecehan seksual. Kasus pertama pelecehan seksual dilakukan oleh Guru Mengaji di Pondok Pesantren Lhokseumawe Aceh. Terdakwa divonis seratus enampuluh bulan penjara dan restitusi berupa lima belas gram kepada orangtua setiap korban. Vonis di Aceh berdasarkan Qanun Aceh. Namun hingga Februari 2020, Penasehat Hukum terdakwa menyatakan banding. ${ }^{4}$

Kasus kedua Pelaku Pelecehan Seksual diduga adalah anak kyai sekaligus petinggi di salah satu Pondok Pesantren di Jombang, Provinsi Jawa Timur. Disebutkan bahwa korban lebih dari satu orang, namun penyidik kesulitan menemukan alat bukti karena minimnya saksi. Kasus tersebut telah dilaporkan ke Polres Jombang pada 29 Oktober 2019 dengan nomor perkara LPB/392/X/Res1,24/09/2019/Jatim/Res.Jbg. Akibat kesulitan menemukan alat bukti tersebut, ditambah pelaku yang ditetapkan menjadi tersangka tidak kooperatif dan mempengaruhi situasi sosial di Jombang, maka korban ditempatkan pada lokasi yang aman dan perkara dilimpahkan ke Polda Jawa Timur sejak 15 Januari 2020.5

3 Ahmad Amri, "Dosen Perlaku Cabul Divonis Satu Tahun Penjara” https://www.lampost.co/beritadosen-pelaku-cabul-divonis-satu-tahun-penjara.html, diakses tanggal 17 Februari 2020.

${ }^{4}$ Saiful Bahri, "Giliran Oknum Guru Mengaji di Pesantren AN Divonis 160 Bulan, Kasus Dugaan Pelecehan Santri, https://aceh.tribunnews.com/2020/01/30/giliran-oknum-guru-mengaii-di-pesantren-andivonis-160-bulan-kasus-dugaan-pelecehan-seksual-santri, diakses 17 Februari 2020.

5 Fadiyah Alaidrus, "Duduk Perkara Skandal Kasus Kekerasan Seksual di Pesantren Jombang", https://tirto.id/duduk-perkara-skandal-kasus-kekerasan-seksual-di-pesantren-jombang-exjo , diakses tanggal 17 Februari 2020. 
Ketiga, pelecehan di transportasi umum. Moda transportasi umum yang seringkali menjadi lokasi pelecehan yakni bus (35.80\%), angkutan umum $((29,49 \%)$, Kereta Rel Listrik (18.14\%), Ojek Dalam Jaringan (4,79\%), dan Ojek yang masih konvensional (4,27\%). ${ }^{6}$

Berdasarkan survei yang dilakukan Koalisi Ruang Publik Aman yang dilakukan terhadap 62.224 responden sepanjang 2018 yang tersebar di seluruh Indonesia terdapat tiga dari lima perempuan yang menggunakan transportasi umum mengalami pelecehan seksual. ${ }^{7}$

Kereta Api merupakan transportasi alternatif paling cepat dan tepat waktu. Namun dari Kereta Api menjadi sumber pelecehan seksual. Tercatat berdasar penelitian awal penulis mendapat data bahwa terjadi pelecehan seksual yang menimpa seorang remaja puteri yang tidak dapat disebutkan inisial namanya di Kereta Rel Listrik tujuan Stasiun Manggarai, Jakarta. Pelaku adalah seorang karyawan di rumah sakit kawasan Jakarta kemudian dilaporkan ke Kantor Kepolisian Daerah Metro Jaya (Polda Metro Jaya) odengan barang bukti baju yang pelaku gunakan pada saat kejadian. Pasal yang dikenakan adalah Pasal 290 KUHP. 8

Keempat, pelecehan seksual di rumah sakit. Berdasarkan temuan Komnas Perlindungan Perempuan, Rumah Sakit Jiwa dan Panti Sosial ada seorang petugas yang memandikan pasien yang menderita disabilitas psikososial. Proses pemandian tersebut dilakukan di lokasi terbuka yang dapat dilihat orang umum. Padahal persepsi bahwa disabilitas psikososial tidak memiliki rasa malu adalah salah. ${ }^{9}$

Temuan kedua adanya pemaksaan penggunaan kontrasepsi yang bermaksud mengatur tingkat kesuburan namun dengan cara merusak organ fungsi reproduksi melalui penggunaan dan pemasangan alat kontrasepsi dan tindakan operasi tertentu (tubektomi) secara paksa. Pada 2018 Komnas Perempuan memberikan pengertian pemaksaan kontrasepsi mengacu pada suatu situasi

6 Khoirur Rozi, "Koalisi Ruang Publik Aman: Banyak yang Belum Tahu Pelecehan", https://www.gatra.com/detail/news/459032/milenial/koalisi-ruang-publik-aman-banyak-yang-belum-tahupelecehan, diakses tanggal 17 Februari 2020.

7 Tim Redaksi CNN Indonesia, "Survei: 3 dari 5 Wanita Alami Pelcehan di Bus Hingga Ojol", https://www.cnnindonesia.com/gaya-hidup/20191128093808-282-452222/survei-3-dari-5-wanita-alamipelecehan-di-bus-hingga-ojol, diakses tanggal 17 Februari 2020.

8 M. Iqbal Al Machmudi, "Seorang Remaja Alami Pelecehan Seksual di Stasiun Manggarai", https://mediaindonesia.com/read/detail/253471-seorang-remaja-alami-pelecehan-seksual-di-stasiun-manggarai , diakses tanggal 17 Februari 2020.

9 Komisi Nasional Anti Kekerasan Terhadap Perempuan, Korban Bersuara, Data Bicara Sabkan Ruu Penghapusan Kekerasan Seksual Sebagai Wujud Komitmen Negara: Catatan Kekerasan Terhadap Perempuan Tabun 2018, Komnas Perempuan, Jakarta, 2019, hlm. 49. 
dimana pasien tidak mendapatkan informasi lengkap dan Pasien tidak medapatkan pandangan lain (second opinion) dalam hal kontrasepsi yang dapat digunakan. Contoh di salah satu panti psikotik di Semarang, seluruh perempuan dalam usia subur, yang akan menjadi penghuni, akan dipasangi alat kontrasepsi jenis susuk Keluarga Berencana (KB). Di Rumah Sakit Jiwa daerah di Semarang, pasien perempuan akan menjalani tubektomi, dengan informed consent dari keluarga pasien. Sementara pasien yang diantarkan oleh Satpol PP setelah melakukan razia di jalanan, prosedur pemasangan kontrasepsi dilakukan tanpa informed consent dari yang bersangkutan. ${ }^{10}$

Temuan ketiga, pelecehan seksual yang dilakukan tenaga keperawatan di rumah sakit yang diviralkan melalui media sosial oleh pelaku. Pada 24 Oktober 2018, seorang Co-pilot salah satu maskapai penerbangan mengalami kecelakaan mobil yang ditumpangi bersama temannya di Surabaya. Korban dibawa ke Instalasi Gawat Darurat RSUD dr Soetomo. Saat dirawat, korban ditelanjangi oleh petugas medis dengan dalih untuk keperluan medis. Petugas membuka pakaian korban dan memotret korban dalam keadaan tanpa busana. Korban menolak tindakan petugas, tetapi tetap dilakukan malah foto tersebut disebar via whatsapp. Pihak keluarga korban yang datang pada pagi hari tidak terima oleh tindakan pelecehan ini dan kemudian melaporkan kasus ini ke Polrestabes Surabaya. Pihak rumah sakit berdalih bahwa ini adalah prosedur yang diperlukan. Padahal yang dilakukan oleh pelaku itu di luar prosedur. Tindakan menyebar foto korban tanpa izin ke whatsapp merupakan tindakan pelecehan seksual dan kekerasan di dunia maya terhadap perempuan. ${ }^{11}$

Temuan keempat terjadi menimpa pasien Rumah Sakit National Hospital Surabaya pada Januari 2018. Pasien yang tengah tidak sadar karena masih dalam pengaruh obat bius paska operasi dipindahkan dari ruang operasi keruang pemulihan, diraba-raba payudaranya oleh perawat laki-laki. Sebagai bentuk pertanggung jawaban, manajemen Rumah Sakit National Hospital Surabaya telah memecat perawat tersebut dan perawat telah diproses hukum. ${ }^{12}$

Pelecehan seksual tidak hanya dilihat dari peristiwa pencabulan melainkan dapat diperluas menjadi berbagai bentuk kekerasan yang pada maksudnya melakukan pelanggaran atas hak tubuh seseorang yang menjurus pelanggaran kesusilaan dan kesopanan. Berdasarkan temuan Komnas Perempuan, umumnya kekerasan fisik yang ditemukan dalam pelecehan seksual menyasar payudara 
korban. ${ }^{13}$ Sehingga berdasarkan paparan penulis diatas, ditemukan banyak jenis pelecehan seksual dan lokasi dimana terjadi pelecehan seksual tersebut.

Oleh karena itu, Penulis akan fokus pada pelecehan seksual terhadap pasien di Rumah Sakit karena masih banyak yang belum membahas dan meneliti hal tersebut. Berdasarkan Undang-Undang Nomor 36 Tahun 2009 tentang Kesehatan Pasal 2 bahwa: "Setiap kegiatan dan upaya untuk meningkatkan derajad kesehatan masyarakat harus dilaksanakan berazaskan perikemanusian, keseimbangan, manfaat, perlindungan, penghormatan terhadap hak dan kewajiban, keadilan, gender dan non diskriminatif dan norma-norma agama".

Berdasarkan Petikan Putusan Nomor 738/Pid.Sus/2018/PN Sby, terdakwa pelecehan seksual pada Temuan Nomor Empat, yakni pelecehan terhadap pasien di Rumah Sakit Surabaya, hanya divonis sembilan bulan penjara dipotong masa tahanan. Terdakwa dikenakan KUHP Pasal 290 ayat (1) dan Undang-Undang Nomor 8 Tahun 1981 tentang Hukum Acara Pidana. Hal tersebut tentu tidak memberikan efek jera dimana bisa saja setelah keluar penjara si pelaku mengulangi kesalahan yang sama dalam profesinya tersebut. Putusan tersebut sudah berkekuatan hukum tetap.

Bahwa kepada setiap pasien korban dari praktek kedokteran dan pelayanan kesehatan yang belum memenuhi standar pelayanan medis, pasien tersebut dapat menuntut haknya. Dokter dan tenaga keperawatan pada dasarnya baru berhadapan dengan hukum apabila timbul kerugian bagi pasien karena adanya kealpaan dan kelalaian yang berbentuk Kewajiban, adanya Pelanggaran, adanya sebab lain dan Kerugian. ${ }^{14}$

Oleh sebab itu penulis tertarik membahas penelitian dengan Judul "Analisis Yuridis Terhadap Tenaga keperawatan yang Melakukan Tindak Pidana Pelecehan Seksual terhadap Pasien".

\section{Rumusan Masalah}

Penulis memberikan rumusan masalah sebagai berikut: Pertama, bagaimana dasar kebijakan tindak pidana pelecehan seksual oleh tenaga keperawatan terhadap pasien dalam perundang-undangan? Kedua, apa sajakah urgensi Lex Specialis dalam pengaturan pidana bagi tenaga keperawatan yang melakukan pelecehan seksual terhadap pasien?

\footnotetext{
${ }^{3}$ Ibid.

${ }^{14}$ Bahdar Johan Nasution, Hukum Kesehatan dan Pertanggungjawaban Dokter, Rhenika Cipta, Jakarta, 2005,
} hlm. 79 . 


\section{Tujuan Penelitian}

Adapun penelitian ini bertujuan untuk: Pertama, mengetahui dasar kebijakan tindak pidana pelecehan seksual oleh tenaga keperawatan terhadap pasien dalam perundang-undangan. Kedua, memahami urgensi Lex Specialis dalam pengaturan pidana bagi tenaga keperawatan yang melakukan pelecehan seksual terhadap pasien.

\section{Metode Penelitian}

Penelitian merupakan kegiatan ilmiah yang berdasarkan pada metode, sistematika dan pemikiran tertentu yang bertujuan untuk mengungkapkan kebenaran, secara sistematis, metodologis, dan konsiten. Penelitian sangat diperlukan untuk memperoleh data yang akurat sehingga dapat menjawab permasalahan sesuai dengan fakta atau data yang ada dan dapat mempertanggungjawabkan kebenarannya. ${ }^{15}$

\section{Jenis Penelitian}

Jenis penelitian yang digunakan oleh penulis dalam penelitian ini adalah penelitian normatif. Penelitian normatif atau metode penelitian hukum kepustakaan adalah metode atau cara yang digunakan di dalam penelitian hukum yang dilakukan dengan cara meneliti bahan pustaka yang ada. 16 Penelitian ini akan mengkaji tentang penegakan hukum pidana tenaga keperawatan yang melakukan pelecehan seksual terhadap pasien di Rumah Sakit dengan melihat norma, peraturan perundang-undangan dan literatur yang terkait pelayanan kesehatan di rumah sakit. Tipe penelitian yang digunakan untuk menjawab permasalahan dan menjelaskan pembahasan adalah tipe deskriptif. Tipe deskriptif bertujuan untuk memperoleh pemaparan (deskripsi) secara lengkap, rinci, jelas, dan sistematis tentang beberapa aspek yang diteliti pada undang-undang, peraturan daerah, naskah kontrak atau objek kajian lainnya. ${ }^{17}$

\section{Pendekatan Penelitian}

Penelitian hukum terdapat beberapa pendekatan, macam-macam pendekatan yang digunakan dalam penelitian hukum adalah pertama, pendekatan undang-undang (statute appoach). Kedua, pendekatan konseptual (conceptual appoach). Penelitian yang dilakukan oleh penulis lebih ditujukan pada pendekatan undang-undang. Pendekatan undang-undang dilakukan dengan menelaah semua

15 Abdurkadir Muhammad, Hukum dan Penelitian Hukum, Citra Aditya Bakti, Bandung, 2004, hlm. 2.

${ }^{16}$ Soerjono Soekanto \& Sri Mamudji, Penelitian Hukum Normatif, Rajawali Press, Jakarta, 2009, hlm. 13.

17 Abdurkadir Muhammad, Op. Cit, hlm. 102 
undang-undang dan regulasi. ${ }^{18}$ Contohnya KUHP dan Undang-Undang Kesehatan.

\section{Obyek penelitian}

Obyek penelitian adalah kajian tentang proses penegakan hukum pidana tenaga keperawatan yang melakukan pelecehan seksual terhadap pasien di Rumah Sakit menurut perspektif Hak Asasi Manusia dan Hukum Pidana.

\section{Data Penelitian atau Bahan Hukum}

Jenis data dapat dilihat dari sumbernya, dapat dibedakan antara data yang diperoleh langsung dari masyarakat dan data yang diperoleh dari bahan pustaka. ${ }^{19}$ Jenis data yang digunakan dalam penelitian ini adalah data sekunder yang diperoleh melalui studi kepustakaan bahan-bahan hukum yang terdiri dari:

\section{Hasil Penelitian dan Pembahasan}

\section{Dasar Kebijakan atas Tindak Pidana Pelecehan Seksual oleh Tenaga Keperawatan terhadap Pasien dalam Peraturan Perundang-Undangan}

Sejak kelahirannya, profesi di bidang kesehatan berusaha menempatkan diri di bidang profesi yang luhur dengan berusaha menempatkan kepentingan pasien diatas kepentingan tenaga kesehatan. Contohnya terhadap kasus pelecehan seksual yang dilakukan oleh perawat terhadap pasien di salah satu Rumah Sakit Swasta di Kota Surabaya. Tindak pidana pelecehan seksual oleh tenaga keperawatan terhadap pasien merupakan indikasi adanya penurunan kualitas dalam menjalankan profesi.

Penurunan kualitas profesi medis secara etika dapat disebabkan oleh beberapa hal yang pertama, kemajuan teknologi yang berkembang pesat, kedua adanya komersialisasi praktik profesi medis, ketiga meningkatnya kesadaran masyarakat mengenai hak dan kewajiban sebagai pasien. Adanya penurunan kemanusiaan dan kepribadian di bidang kesehatan tidak serta merta karena ilmu, teknologi atau ekonomi namun karena krisis kepercayaan antara pasien dengan tenaga kesehatan. ${ }^{20}$

Guna melindungi hubungan yang tidak seimbang antara pasien maupun tenaga kesejahatan itu sendiri maka profesi tenaga kesehatan diharuskan mengucap ikrar sumpah oleh anggota tenaga kesehatan dan di dalam ikrar sumpah tersebut

${ }^{18}$ Peter Mahmud Marzuki, Penelitian Hukum, Kencana Prenada, Jakarta, 2008, hlm. 93.

${ }^{19}$ Soerjono Soekanto \& Sri Mamudji, Op. Cit., hlm. 11.

${ }^{20}$ Yanuar Amin, Bahan Ajar Teknologi Laboratorium Medis (TLM) Pusat Pendidikan Sumber Daya Manusia Kesehatan Badan Pengembangan dan Pemberdayaan Sumber Daya Manusia Kesehatan Edisi, Kementerian Kesehatan Republik Indonesia, Jakarta, 2017, hlm. 191 
pernyataan akan menaati kode etik. Fungsi ikrar menjadi penjamin bagi pasien bahwa profesi tenaga kesehatan dapat dipercaya dan akan senantiasa tidak merugikan pasien. Ikrar sumpah profesi tenaga kesehatan merupakan implementasi dari prinsip-prinsip etika moral bioetika dalam hubungan tenaga kesehatan dan pasien adalah berbuat baik, tidak merugikan, menghormati otonomi pasien dan keadilan. Sejalan dengan perkembangan sosiologi masyarakat, maka akan ada perubahan dalam implementasi prinsip-prinsip di atas. ${ }^{21}$

Dewasa ini masyarakat mengetahui standar mutu profesi tenaga kesehatan telah tercakup dalam kode etik. Kode etik perawat Pasal 4 Bagian Perawat dan Praktik disebutkan bahwa perawat harus menunjukkan perilaku profesional serta senantiasa menjunjung tinggi nama baik profesi. Melalui komite keperawatan rumah sakit dan Komisariat Persatuan Perawat Nasional Indonesia (PPNI) harus membina perawatnya. Namun dalam Kode Etik Perawat tidak disebutkan pengaturan tindak pidana, melainkan disebutkan adanya pelanggaran disiplin.

Meski demikian, Kode Etik dapat menjadi dasar pertimbangan hakim dalam memutus tenaga keperawatan melakukan tindakan pelecehan seksual atau tidak yaitu melalui hasil rapat Majelis Tenaga Kesehatan Indonesia (MTKI). Majelis Tenaga Kesehatan Indonesia (MTKI) berdiri berdasarkan Permenkes Nomor 1796 Tahun 2011 tentang Registrasi Tenaga Kesehatan yang menjamin tenaga kesehatan ini mempunyai Surat Tanda Registrasi (STR) setelah lulus ujian kompetensi. MTKI ini juga memiliki Komite disiplin Tenaga Kesehatan yang bertugas meneliti dan menentukan ada atau tidak adanya kesalahan atau kelalaian dalam menerapkan standar profesi yang dilakukan oleh tenaga kesehatan dalam memberikan pelayanan kesehatan; memanggil atau meminta keterangan dari tenaga kesehatan yang diadukan, penerima pelayanan kesehatan yang merasa dirugikan, dan saksi; melakukan pemeriksaan di lapangan atau hal lain yang dianggap perlu; melakukan kerja sama dengan pemangku kepentingan terkait dalam rangka uji kompetensi, sertifikasi, registrasi dan lisensi bagi tenaga kesehatan; dan melakukan penilaian terhadap kemampuan tenaga kesehatan dan tindakan administratif bagi tenaga kesehatan yang tidak menjalankan praktik atau pekerjaannya sasuai ketentuan.

Hasil dari Komite inilah yang akan memperkuat atau menyanggah proses pembuktian dalam proses hukum tindak pidana. Kasus tindakan pelecehan seksual yang menimpa Pasien W kemudian diproses sidang pada 3 Februari 2018 dengan hasil Majelis Kode Etik Keperawatan (MKEK) Jawa Timur memutuskan 
Tenaga Keperawatan belum tentu melanggar hukum karena tindakannya tercakup dalam prosedur medis dan tidak melanggar etika keperawatan. ${ }^{22}$

Hasil putusan MKEK tentu meringankan Tuntutan Jaksa dan memberikan pertimbangan kepada hakim. Pada akhirnya berdasarkan Petikan Putusan Nomor 738/Pid.Sus/2018/PN Sby perawat berinisial Z tersebut tetap divonis melakukan tindakan pidana berupa Pencabulan terhadap Pasien dijatuhi pidana penjara selama sembilan bulan berdasar KUHP Pasal 290 ayat 1.

Berbicara dari sisi Perlindungan Hukum dan Hak Asasi Manusia, sebagai Korban, $\mathrm{W}$ juga tidak terlindungi secara hukum karena identitasnya sebagai korban dicantumkan dengan jelas di Putusan. Berdasarkan Undang-Undang Republik Indonesia Nomor 31 Tahun 2014 tentang Perubahan Atas Undang-Undang Nomor 13 Tahun 2006 tentang Perlindungan Saksi dan Korban Pasal 1 ayat (3) yang menyebutkan Korban adalah orang yang mengalami penderitaan fisik, mental, dan/atau kerugian ekonomi yang diakibatkan oleh suatu tindak pidana. Selanjutnya Pasal 5 ayat 1 huruf i Saksi dan Korban berhak dirahasiakan identitasnya.

Demikianlah peraturan hukum selalu mengalami dinamika sehingga memerlukan suatu perubahan dengan cara pembaharuan yang tentunya harus disesuaikan dengan perubahan zaman. Oleh sebab itu, pembangunan di bidang hukum suatu negara wajib mendapatkan tempat yang utama dalam perkembangan suatu negara. Selain itu pembangunan hukum seyogyanya tidak saling bertentangan antara peraturan perundang-undangan yang satu dengan lainnya di dalam tertib hukum. ${ }^{23}$

Praktik hukum yang banyak kendala mengindikasikan adanya ketidaktertiban hukum. Dimana pihak perawat dan persatuannya tidak terima atas tuduhan melakukan tindak pidana pelecehan seksual dengan alasan kriminalisasi. Kemudian ditambah pihak rumah sakit tidak merasa ikut bertanggungjawab atas perbuatan oknum perawat. Kemudian secara tegas belum ada aturan hukum pidana maupun hukum kesehatan yang secara khusus mengatur pelecehan seksual yang dilakukan oleh Pelaku yang terikat profesi semacam tenaga keperawatan secara personal maupun organisasi yang mampu secara komprehensif melindungi korban.

Maka itu dinamika hukum yang perlu dibenahi adalah mengenai tindak pidana pelecehan seksual. Tindak pidana pelecehan seksual baru muncul pada 2015. Masih tergolong baru dibandingkan tindak pidana korupsi dan

22 Artika Rachmi Farmita, "Persatuan Perawat Bela Tersangka Pelecehan di National Hospital", https://nasional.tempo.co/read/1058114/persatuan-perawat-bela-tersangka-pelecehan-di-national-hospital, diakses tanggal 25 Maret 2020.

23 Yanuar Amin, Op. Cit., hlm. 77 
Pembunuhan. Tercatat adanya peningkatan Jumlah tindak pidana Pelecehan Seksual sejak 2015 hingga 2020. Apabila 2015 kasus pelecehan seksual pada awalnya hanya dilakukan di sekitar tempat tinggal korban maka 2019 telah berubah. Segi kuantitas dibuktikan dengan adanya sejumlah kasus yang penulis temukan dalam empat lingkungan yang berbeda yaitu lingkungan industri film, pendidikan, transportasi umum dan rumah sakit.

\section{Urgensi Lex Spesialis dalam Pengaturan Pidana bagi Tenaga Keperawatan yang Melakukan Pelecehan Seksual terhadap Pasien}

Norma Lex Spesialis berada tepatnya di Pasal 63 ayat (2) KUHP yang menyatakan bahwasanya apabila tindakan masuk dalam ketentuan pidana umum, namun juga termasuk didalam ketentuan pidana khusus, maka aturan yang khusus tersebut yang akan diterapkan. Tapi Kitab Undang-Undang Hukum Pidana tidak menjelaskan dengan detail bagaimana situasi dan kondisi contoh peristiwa hukum dan kenyataan penerapan hukumnya di lapangan.

Beberapa alasan urgensi lex spesialis dalam tindak pidana pelecehan seksual karena:

Pertama, Penulis menemukan beberapa peraturan perundang-undangan yang tidak relevan dan ambivalen terhadap tindak pidana pelecehan seksual. Hukum yang berbentuk tertulis termasuk peraturan perundang-undangan berfungsi sebagai corak utama dalam sistem hukum negara Indonesia. Sehingga memerlukan kepastian hukum dalam rangka menjaga sinergitas yang dibangun dalam masyarakat dan pemerintah guna mewujudkan tujuan bernegara secara relevan dan tertib. ${ }^{24}$

Contohnya pada kasus di Rumah Sakit Swasta di Surabaya, pelaku dikenakan KUHP Pasal 290 ayat (1) " barang siapa melakukan perbuatan cabul dengan seorang, padahal diketahuinya bahwa orang itu pingsan atau tidak berdaya" diancam dengan pidana penjara paling lama tujuh tahun. Berdasarkan Petikan Putusan Nomor 738/Pid.Sus/2018/PN Sby perawat melakukan tindakan pidana berupa Pencabulan terhadap Pasien dijatuhi pidana penjara selama 9 bulan.

Hal ini juga menjadi polemik karena pasal pencabulan yang diancamkan tidak sesuai dengan nomenklatur tentang pelecehan seksual. Pelecehan Seksual artinya adalah tindakan seksual yang dilakukan melalui sentuhan fisik dan atau non-fisik dengan tujuan yang disasar adalah organ seksual atau seksualitas korban. Pelecehan seksual meliputi siulan, main mata, kata-kata tentang seksual, mempertunjukan materi pornografi dan keinginan seksual, colekan atau sentuhan

24 Rosita, Proses Pengharmonisasian Sebagai Upaya Meningkatkan Kualitas Peraturan PerundangUndangan.” Menggagas Arah Kebijakan Reformasi Regulasi di Indonesia hlm. 328 
secara paksa atau iseng di bagian tubuh korban, tindakan yang bersifat seksual sehingga akibatnya korban merasa tidak nyaman, tersinggung atau merasa direndahkan martabatnya, dan atau hingga mempengaruhi masalah kesehatan fisik atau mental serta keselamatan. ${ }^{25}$ Penggunaan istilah Pencabulan menjadikan Pelecehan Seksual memiliki arti sempit yakni hanya sebatas hubungan fisik yang tidak dikehendaki. Padahal pelecehan Seksual sendiri memiliki arti yang luas.

Undang-Undang Nomor 39 Tahun 1999 tentang Hak Asasi Manusia dalam norma hak untuk bebas dari pelecehan seksual. namun tanpa rumusan unsur tindak pidana dan ancaman pidana.

Demikian juga dengan Undang-Undang Republik Indonesia Nomor 36 Tahun 2014 tentang Tenaga Kesehatan Pasal 84 yang hanya menyebutkan hanya Tenaga Kesehatan yang menyebabkan Luka Berat atau kematian baru dapat dipidana.

Kedua, peraturan perundang-undangan yang dirancang tidak sinkron dengan peraturan lainnya. Maksud penulis adalah Rancangan Undang-Undang Penghapusan Kekerasan Seksual (RUU PKS) oleh Dewan Perwakilan Rakyat (DPR) berbeda dengan RUU PKS oleh Pemerintah. RUU PKS seharusnya melibatkan beberapa instansi seperti DPR dan pemerintah (sebagai pembuat kebijakan), Polri (sebagai aparat di lapangan), Komisi Perempuan dan Anak (sebagai perwakilan korban Kekerasan Seksual), Badan Pusat Statistik (sebagai pengolah dan penyaji data Pelecehan seksual di seluruh Indonesia), Kalangan Profesional yang memiliki Organisasi Perkumpulan Profesi (sebagai pihak pemerhati dan akademisi). Sehingga semua pendapat bisa didengar dan dipertimbangkan. Namun kenyataan yang ada hanya dua pihak yang bermusyawarah yaitu DPR dan Pemerintah saja.

Pelecehan seksual dan pencabulan berbeda namun disamakan nomenklaturnya. Pemerintah beralasan dalam penghapusan tindak pidana pelecehan seksual dalam RUU PKS karena tindak pidana pelecehan seksual telah termasuk dalam Tindak Pidana Pencabulan. ${ }^{26}$ Selanjutnya masih memerlukan harmonisasi antara RUU PKS dengan RKUHP dengan konsekuensi dan kondisi sebagai berikut:

Pertama, apabila RUU PKS tidak dimasukkan pada RKUHP, maka konsekuensi yang dapat terjadi adalah ketentuan umum pidana akan tetap

25 Tim Penyusun, Potret Awal Tujuan pembangunan Berkelanjutan (Suistanable Development Goals) di Indonesia, Badan Pusat Statistik, Jakarta, hlm. 6.

${ }^{26}$ Tim Penyusun, RUU DPR Versus DIM Pemerintah: Melihat Posisi DPR dan Pemerintah Atas Rancangan Undang-Undang tentang Penghapusan Kekerasan Seksual, Institute for Criminal Justice Reform, 2017, hlm. 31 
tunduk pada Buku I RKUHP, setidaknya pelaku dapat memilih ketentuan umum mana yang menguntungkan bagi dirinya.

Kedua, apabila pengaturan tindak pidana perkosaan dimasukkan pada buku II RKUHP, maka seluruh ketentuan pidana perkosaan/pelecehan seksual pada RUU PKS dapat hilang. Apabila RUU PKS akan disahkan maka perlu perubahan dalam aturan peralihan dalam RKUHP terlebih dahulu. ${ }^{27}$

Pengaturan tindak pidana pelecehan seksual seyogyanya dibuat mengacu pada dasar kebijakan dan peraturan yang ada dan tidak berdiri sendiri-sendiri. Pengaturan tindak pidana pelecehan seksual yang benar setidak-tidaknya memuat beberapa indikator yaitu: 1. Mengacu pada nilai-nilai Pancasila; 2. Berorientasi perlindungan korban; 3. Memberikan pencegahan supaya tidak jatuh korban lebih banyak dan perbuatan tindak pidana yang melebihi pelecehan seksual; 4. Mengatur pemberatan terhadap pelaku yang memiliki profesi tertentu; 5. Mengatur pemberatan terhadap pelaku yang seharusnya melindungi korban; 6 . Memiliki hubungan harmoni dengan peraturan perundang-undangan yang lain

\section{Penutup}

Berdasarkan uraian pembahasan di atas maka diambil kesimpulan bahwa kebijakan atas tindak pidana pelecehan seksual oleh Tenaga keperawatan terhadap Pasien berdasarkan beberapa faktor: Pertama, kasus pelecehan seksual terhadap pasien mengindikasikan adanya penurunan kualitas dalam menjalankan profesi. Kedua, kode etik perawat tidak menyebutkan pengaturan tindak pidana, melainkan disebutkan adanya pelanggaran disiplin. Konsekuensinya adalah Kode etik hanya akan dijadikan dasar pertimbangan hakim yaitu melalui hasil rapat Majelis Tenaga Kesehatan Indonesia (MTKI) yang memiliki Komite disiplin Tenaga Kesehatan. Ketiga, praktik hukum dalam Putusan Nomor 738/Pid.Sus/2018/PN Sby tidak mendukung implementasi Kode Etik karena Majelis hakim mengesampingkan Hasil rapat Majelis Tenaga Kesehatan Indonesia (MTKI). Keempat, majelis hakim dalam Putusan Nomor 738/Pid.Sus/2018/PN Sby masih menggunakan landasan hukum yang umum dan lama yaitu Pasal 290 ayat 1 KUHP tentang Pencabulan. Kelima, ketiadaan perlindungan hukum bagi pasien dimana saksi dan korban tidak mendapat pertanggungjawaban hukum dari pihak Rumah Sakit dan identitasnya terbuka ke publik.

Sedangkan urgensi lex spesialis pengaturan tindak pidana pelecehan seksual oleh Tenaga keperawatan terhadap pasien antara lain: Pertama, peraturan yang

27 Tim Penulis, Reformasi Pengaturan Tindak Pidana Perkosaan, Masyarakat Pemantau Peradilan Indonesia dan Badan Penerbit Fakultas Hukum Universitas Indonesia atas dukungan Australia Indonesia Partnership for Justice, Jakarta, hlm. 132. 
ada tidak relevan. Pasal Pelecehan Seksual tidak ada kemudian digantikan Pasal Pencabulan sebagaimana tertuang dalam Petikan Putusan Nomor 738/Pid.Sus/2018/PN Sby. Kemudian dalam Undang-Undang Nomor 39 Tahun 1999 tentang Hak Asasi Manusia ada kata-kata berupa hak untuk bebas dari pelecehan seksual, namun tidak ada penjelasan mengenai pengertian, unsur tindak pidana dan ancaman pidana. Kedua, peraturan yang tidak sinkron. Aturan hukum yang ada belum diimplementasikan dengan tepat dan terintegrasi dengan Hukum Acara. Contohnya sudah ada Undang-Undang Nomor 36 Tahun 2014 tentang Tenaga kesehatan, Undang-Undang Nomor 44 Tahun 2009 tentang Rumah sakit, Undang-Undang Republik Indonesia Nomor 31 Tahun 2014 tentang Perubahan Atas Undang-Undang Nomor 13 Tahun 2006 tentang Perlindungan Saksi dan Korban, Peraturan Pemerintah No. 32 Tahun 1996 tentang Standar Profesi Tenaga Kesehatan, peraturan Menteri Kesehatan Republik Indonesia Nomor 49 Tahun 2013 tentang Komite Keperawatan Rumah Sakit, Permenkes Nomor 1796 Tahun 2011 tentang Registrasi Tenaga Kesehatan.

\section{Daftar Pustaka}

\section{Buku}

Amin, Yanuar, Bahan Ajar Teknologi Laboratorium Medis (TLM) Pusat Pendidikan Sumber Daya Manusia Kesehatan Badan Pengembangan dan Pemberdayaan Sumber Daya Manusia Kesehatan Edisi, Kementerian Kesehatan Republik Indonesia, Jakarta, 2017.

Azhari, Negara Hukum, UI Press, Jakarta, 1955.

Komisi Nasional Anti Kekerasan Terhadap Perempuan, Korban Bersuara, Data Bicara Sahkan Ruu Penghapusan Kekerasan Seksual Sebagai Wujud Komitmen Negara: Catatan Kekerasan Terhadap Perempuan Tahun 2018, Komnas Perempuan, Jakarta, 2019.

Marzuki, Peter Mahmud, Penelitian Hukum, Kencana Prenada, Jakarta, 2008.

Muhammad, Abdulkadir, Hukum dan Penelitian Hukum, Citra Aditya Bakti, Bandung, 2004.

Nasution, Johan Bahdar, Hukum Kesehatan dan Pertanggungjawaban Dokter, Rhenika Cipta, Jakarta, 2005.

Soekanto, Soerjono dan Sri Mamudji, Penelitian Hukum Normatif, Rajawali Press, Jakarta, 2009.

Tim Penulis, Reformasi Pengaturan Tindak Pidana Perkosaan, Masyarakat Pemantau Peradilan Indonesia dan Badan Penerbit Fakultas Hukum Universitas Indonesia atas dukungan Australia Indonesia Partnership for Justice, Jakarta.

Tim Penyusun, Potret Awal Tujuan pembangunan Berkelanjutan (Suistanable Development Goals) di Indonesia, Badan Pusat Statistik, Jakarta, 2018. 
Tim Penyusun, RUU DPR Versus DIM Pemerintah: Melihat Posisi DPR dan Pemerintah Atas Rancangan Undang-Undang tentang Penghapusan Kekerasan Seksual, Institute for Criminal Justice Reform, Jakarta, 2017.

\section{Jurnal}

Nazruzila Razniza Binti Mohd Nadzri,Malaysian Employment Laws: Trcking The Recent Updates, South east Asian Journal of Contemporary Business, Economics and Law Volume 12012.

\section{Makalah}

Indrayati, Rosita "Urgensi Harmonisasi dan Sinkronisasi Sebagai Bentuk Penguatan dan Peningkatan Kualitas Regulasi di Indonesia: Menggagas Arah Kebijakan Reformasi Regulasi di Indonesia", Prosiding, Forum Akademik Kebijakan Reformasi Regulasi 2019 atas dukungan dan kerja sama dengan Pemerintah Kerajaan Belanda melalui Program Rule of Law Fund serta International Development Law Organization (IDLO).

Internet:

Adam, Aulia, "Pelecehan Seksual di Industri Film dan Suara Nyalang Mian Tiara", https://tirto.id/pelecehan-seksual-di-industri-film-dan-suara-nyalangmian-tiara-ey1Q, diakses tanggal 17 Februari 2020.

Alaidrus, Fadiyah, "Duduk Perkara Skandal Kasus Kekerasan Seksual di Pesantren Jombang", $\quad$ https://tirto.id/duduk-perkara-skandal-kasus-kekerasanseksual-di-pesantren-jombang-exjo, diakses tanggal 17 Februari 2020.

Al Machmudi, M. Iqbal, "Seorang Remaja Alami Pelecehan Seksual di Stasiun Manggarai", https://mediaindonesia.com/read/detail/253471-seorangremaja-alami-pelecehan-seksual-di-stasiun-manggarai , diakses tanggal 17 Februari 2020.

Amri, Ahmad, "Dosen Perlaku Cabul Divonis Satu Tahun Penjara" https://www.lampost.co/berita-dosen-pelaku-cabul-divonis-satu-tahunpenjara.html, diakses tanggal 17 Februari 2020.

Bahri, Saiful, "Giliran Oknum Guru Mengaji di Pesantren AN Divonis 160 Bulan, Kasus Dugaan Pelecehan Santri, https://aceh.tribunnews.com/2020/01/ 30/giliran-oknum-guru-mengaji-di-pesantren-an-divonis-160-bulan-kasusdugaan-pelecehan-seksual-santri, diakses 17 Februari 2020.

Farmita, Artika Rachmi, "Persatuan Perawat Bela Tersangka Pelecehan di National Hospital", https://nasional.tempo.co/read/1058114/persatuan-perawatbela-tersangka-pelecehan-di-national-hospital, diakses tanggal 25 Maret 2020.

Rozi, Khoirur, “Koalisi Ruang Publik Aman: Banyak yang Belum Tahu Pelecehan”, https:// www.gatra.com/detail/news/459032/milenial/koalisi-ruangpublik-aman-banyak-yang-belum-tahu-pelecehan, diakses tanggal 17 Februari 2020.

Tim Redaksi CNN Indonesia, "Survei: 3 dari 5 Wanita Alami Pelcehan di Bus Hingga Ojol", https://www.cnnindonesia.com/gaya- 
hidup/20191128093808-282-452222/ survei-3-dari-5-wanita-alamipelecehan-di-bus-hingga-ojol , diakses tanggal 17 Februari 2020.

\section{Peraturan Perundang-undangan}

UUD NRI 1945.

Kitab Undang-Undang Hukum Pidana (KUHP).

Undang-Undang Nomor 39 Tahun 1999 tentang Hak Asasi Manusia.

Undang-Undang Nomor 36 Tahun 2009 tentang Kesehatan (Lembaran Negara Republik Indonesia Tahun 2004 Nomor 114, Tambahan Lembaran Negara Republik Indonesia Nomor 5063).

Undang-Undang Nomor 44 Tahun 2009 tentang Rumah Sakit (Lembaran Negara Republik Indonesia Tahun 2009 Nomor 153, Tambahan Lembaran Negara Republik Indonesia Nomor 5072.

Undang-Undang Nomor 36 Tahun 2014 tentang Tenaga Kesehatan.

Undang-Undang No. 38 Tahun 2014 tentang Keperawatan.

Undang-Undang Republik Indonesia Nomor 31 Tahun 2014 tentang Perubahan Atas Undang-Undang Nomor 13 Tahun 2006 tentang Perlindungan Saksi dan Korban

Undang-Undang Nomor 18 Tahun 2014 tentang Kesehatan Jiwa.

Peraturan Pemerintah No. 32 Tahun 1996 tentang Standar Profesi Tenaga Kesehatan

Peraturan Menteri Kesehatan Republik Indonesia Nomor 49 Tahun 2013 tentang Komite Keperawatan Rumah Sakit.

Peraturan Menteri Kesehatan Republik Indonesia Nomor 1796 Tahun 2011 tentang Registrasi Tenaga Kesehatan. 